Special issue: Chile's Popular Unity at 50

Article

\section{Protest and the persistence of the past}

\author{
Alison J. Bruey \\ Professor of History, University of North Florida, USA; alison.bruey@unf.edu
}

How to Cite: Bruey, A.J. 'Protest and the persistence of the past'. Radical Americas 6, 1 (2021): 1. DOI: https://doi.org/10.14324/111.444.ra.2021.v6.1.001.

Submission date: 11 September 2020; Acceptance date: 12 October 2020; Publication date: 20 January 2021

\section{Peer review:}

This article has been peer-reviewed through the journal's standard double-blind peer review, where both the reviewers and authors are anonymized during review.

\section{Copyright:}

(C) 2021, Alison J. Bruey. This is an open access article distributed under the terms of the Creative Commons Attribution Licence (CC BY) 4.0 https://creativecommons.org/licenses/by/4.0/, which permits unrestricted use, distribution and reproduction in any medium, provided the original author and source are credited $\bullet$ DOI: https://doi.org/10.14324/111.444.ra.2021.v6.1.001.

\section{Open access:}

Radical Americas is a peer-reviewed open access journal.

\begin{abstract}
Protest has long been a motor of change in Chile. In October to December 2019 protesters in Santiago harnessed protest methods and memories of hope and change related to Salvador Allende's Popular Unity government (1970-3), resistance to the Pinochet dictatorship (1973-90) and discontent with the subsequent decades of neoliberal democracy (1990-2019). The 2019 protests evoked this past in the struggle against the neoliberal system of today. In doing so, the protests offer a complex demonstration of temporal bridging that provides a window onto protest culture and the persistence of the past in contemporary Chile.
\end{abstract}

Keywords: Allende; Chile; democracy; neoliberalism; Pinochet; politics; Popular Unity; protest 
On 19 October 2019, Chilean president Sebastián Piñera declared a state of emergency, sending the military into the streets of Santiago to quell political protest for the first time since the Pinochet dictatorship. ${ }^{1}$ This followed a week of escalating social unrest and protests against a public transport fare hike that was but the tip of the iceberg of citizens' discontent with el modelo (Chile's neoliberal political and economic system). ${ }^{2}$ As the protests persisted and spread, government officials made public comments that only fuelled the fire. Minister of Treasury Felipe Larraín invited people to purchase flowers, pointing out that flower prices were down 3.7 per cent. ${ }^{3}$ Let them eat cake.

Public officials' wilful ignorance and arrogant dismissal of the daily reality of public transport conditions, working- and middle-class households' unsustainable debts, salaries untethered from the actual cost of living and unstable employment, were but a few examples of the structural violence that has long plagued Chile. ${ }^{4}$ It was not surprising to see wealthy right-wing politicians wash their hands of the majority of Chileans who sustain - with their productive and reproductive labour, miserable wages, and stoic endurance of quotidian indignities large and small - the neoliberal economic system that has disproportionately benefited an elite that built fortunes during the Pinochet years and has continued to accumulate wealth since. Sebastián Piñera and his administration represent this generation who travelled the road from beneficiaries of the dictatorship to positions of economic and political power in the new neoliberal democracy. ${ }^{5}$ The tone-deaf response to the fare hike protests, coupled with attempts to criminalize and repress the protesters - mainly secondary school students, who enjoyed the tacit support of significant segments of the adult public - provoked widespread ire. ${ }^{6}$

Ramped-up police repression in the metro, government threats to deploy the State Security Law and boiling discontent catalysed an explosion of social unrest on 18 October that disrupted transport and commerce. When, in the early morning hours of 19 October, Piñera declared a state of emergency and sent troops into the streets to join the Carabineros (uniformed police), his administration responded just as the conservative elite traditionally has done when confronted with challenges from below to the social status quo. For the remainder of 2019 Chileans would endure what Amnesty International has described as 'the worst human rights crisis since the civic-military dictatorship of general Augusto Pinochet'. ${ }^{7}$ Reports of violations by Amnesty International, the United Nations, Chile's Instituto Nacional de Derechos Humanos and the Inter-American Commission on Human Rights include as many as 13,000 injured, over 2,500 charges of human rights violations (1,500 for torture and abuse), 26 deaths and over 20,000 detentions. ${ }^{8}$ The Amnesty International report found that the state applied excessive force meant to injure and punish protesters and that the security forces intentionally injured people to discourage protest. ${ }^{9}$ State agents abused and tortured detainees, hit protesters with vehicles, employed chemical weapons such as tear gas and fired projectiles at close range directly at protesters' bodies. The police permanently blinded hundreds of people in one or both eyes, broke bones, provoked respiratory crises and skin irritation with chemical agents, sexually abused detainees and caused other grave and irreparable injuries. Reports appeared of state agents taking activists from their homes at night, and police attacked medical brigades trying to assist injured protesters. In other words, the government sought to terrorize the population into submission.

This use of what the historian Peter Winn has called 'didactic violence' is a recurring feature of political and social dynamics in Chile. The use of violence 'reflected the elite's determination to defeat challenges to a social hierarchy that the elite viewed as both "natural" and necessary. Their violent response was not only meant to punish those who had challenged this "natural" social order', which in 2019 was the naturalized neoliberal model that formed the foundation of Chile's current status quo, 'but also as a didactic violence to discourage those who might be tempted to challenge it in the future' ${ }^{10}$ While the repression of 2019 did not descend to the levels of past massacres or the unrestrained state terrorism of the Pinochet dictatorship, it is a new chapter in that ongoing history of violence and impunity. ${ }^{11}$

The government also mobilized discursive tactics and political strategies to encourage rejection of the protesters and persuade people to disassociate themselves from the protests. Piñera's announcement, after declaring the state of emergency, that 'we're at war against a powerful enemy' raised alarm and resurrected fears in a society still scarred by seventeen years of violent dictatorship. ${ }^{12}$ The demonization and criminalization of protesters in the media was a common tactic. The government and sympathetic 
media outlets characterized the protesters as vandals, criminals and purveyors of violence and hate. Piñera also blamed the unrest on foreign intervention and subversion. On the public relations side, Piñera proposed a series of social policy reforms that did not adequately address underlying problems and did little to calm the crisis. The government commissioned an 'inspiring' messaging campaign to market its way out of the crisis; this also failed. In December, Piñera apologized for 'errors' and again announced social policy reform measures that fell short of demands. ${ }^{13}$ The political elite has long used these types of discursive and political manoeuvres in tandem with repression to influence, discipline and diminish movements for change.

The elite's recourse to state-perpetrated repression and political manoeuvring is not the only dynamic with long historical roots in Chilean political culture. Historically, protest has been a motor of political and social change in Chile. ${ }^{14}$ Many of the protest methods that appeared in Santiago in 2019 are historical elements of protest culture. Protesters channelled and harnessed the memories of hope and change during Salvador Allende's Popular Unity (UP) government (1970-3), resistance to the Pinochet dictatorship (1973-90) and discontent with the subsequent decades of neoliberal democracy (1990-2019). In 2019, in the space of about six weeks, an estimated 5-6 million people mobilized in pursuit of change. ${ }^{15}$ The mass demonstrations expressed desires for democratic alternatives to Chile's neoliberal system. What was a free-market utopia for some had become an economic, political and social dystopia for many.

The most recent historical experience of democracy prior to the shift from dictatorship to restricted neoliberal democracy in 1990 was the Popular Unity period of 50 years ago (1970-3). Though protesters were not collectively calling for socialism - the estimated one-third of the national population that was in the streets represented a politically heterogeneous cross-section of Chilean society ${ }^{16}$ - the UP remains a cultural touchstone for many insomuch as it represents a historically concrete, alternative form of democracy that enacted ideals contrary to the individualist and consumerist values of the contemporary neoliberal status quo. The 2019 protests evoked this past as well as the struggle against the dictatorship that destroyed it and imposed the neoliberal system of today. In doing so, the protests offer a complex demonstration of temporal bridging that provides a window onto the historical development of protest culture and the persistence of the past in contemporary Chile.

\section{It's not 30 pesos, it's 30 years}

The rapid spread of protest in October 2019 and the state's quick recourse to heavy-handed repression sent international onlookers scrambling to explain what was happening in a country that only seven months prior made headlines as the happiest in South America. ${ }^{17}$ As late as 8 October, President Piñera was on television describing Chile as an 'oasis' of stable democracy and economic growth amidst a 'convulsing Latin America' ${ }^{18}$ It soon became apparent that the protesters jumping metro turnstiles, the youth who attacked symbols of the state and capital (e.g. metro stations, pharmacies, and Líder - Walmart), ${ }^{19}$ the thousands who banged pots and pans (caceroleo) inside their homes and the millions of peaceful protesters who filled the country's avenues over the following weeks begged to differ. What international observers were witnessing was not an irrational or unpredictable explosion but rather the final collapse of a myth and marketing image. October 2019 was the result of a long, slow burn that smouldered for years as Chile's neoliberal democracy success story eroded from within. ${ }^{20}$ In the aftermath of the first week of protest, with soldiers on patrol and the government's democratic credentials shredded, the democracy was now in the streets, demanding Piñera's capitulation and a constitutional assembly to re-establish the legal foundations of the economic and political system. ${ }^{21}$

In the post-dictatorial 1990s, a new political elite coalesced as a segment of the dictatorship's opponents, embodied in the centrist Concertación coalition, entered the halls of government alongside the right. The Concertación held the reins of executive power from 1990 to 2010 and 2014 to 2018 (as the Nueva Mayoría), sharing power with the right in the legislature and at the municipal level. ${ }^{22}$ During the interminable transition, now 30 years and counting, the dictatorship's supporters and enablers, who managed to navigate the change of command, retained their economic and political power as successive concertacionista administrations maintained the economic and political system enshrined in the dictatorship's 1980 Constitution. Despite the Concertación's campaign promises of greater equality and 
democratization throughout the 1990s, near the turn of the century harsh critiques of the new neoliberal democracy had arisen among the extra-parliamentary left and in Santiago's poor and working-class neighbourhoods (poblaciones), although they had little influence on mainstream discourse. ${ }^{23}$ In the poblaciones, disillusionment coexisted with buy-in to capitalist consumerist dreams and an electoral turn to the right.

Hope for change nevertheless endured as new political developments pierced the gathering clouds of cognitive dissonance: in the 1999 presidential election cycle Ricardo Lagos edged out the hard-right UDI candidate, Joaquín Lavín, to become the first Socialist president since Salvador Allende. Lagos's campaign promise, crecer con igualdad (growth with equality) and renewed attention to redress for human rights abuses perpetrated during the dictatorship seemed to proffer change. In 2006, Michelle Bachelet, also of the Socialist Party, became Chile's first female president. She appointed men and women in equal numbers to her cabinet. She also brought a non-traditional family structure and, at least symbolically, the drastically persecuted left of the 1970s into the legitimizing embrace of presidential office. ${ }^{24}$ Yet while some things changed, others did not. By the 2010s, years of impunity for human rights violators in dictatorship and democracy; repression of public protest; and social, political and economic marginalization had taken their toll, as had the repeated experience of seeing attempts at change repressed, co-opted or otherwise curtailed by the government of the moment. Between 2006 and 2011, secondary school student protests were absorbed and defanged with no substantial change to Chile's tremendously unequal educational system. As Bachelet's presidential term ended and Piñera's began, the earthquake of 27 February 2010 revealed fragility and deadly failures in the state's hollowed-out regulatory and response capacities. In 2011, university student protests brought the commodification of education to national and international attention, but the movement foundered as years passed and the state repressed protest, co-opted leadership and absorbed demands without addressing fundamental causes. Bachelet's second presidential administration as part of the Nueva Mayoría (2014-18) put an end to the binomial electoral system but did not substantially change the neoliberal modelo, although the university student protests had done much to bring criticism of it into the mainstream. ${ }^{25}$

During the 2010s, state-perpetrated repression and stark socio-economic inequality, highlighted by ever-more-frequent mass protests, prompted comparisons between the dictatorship and the twenty-first-century neoliberal democracy such that emphasis on the continuities between these historical periods seeped further into public discourse. During the 2010s, social movement collectives mobilized in multiple areas of national life in pursuit of indigenous rights, environmental protections, affordable quality education, women's rights, and labor and pension system reform. In May 2018, women took to the streets in a newly invigorated feminist movement that built upon deep historical currents of feminism and Chilean women's movements for change. ${ }^{26}$ The Mapuche movement, which has long sought to safeguard indigenous communities, lands and lifeways from further despoilment, came ever further into national view as the movement grew and the state escalated repression. ${ }^{27}$ By late 2018, protests by students, women and supporters of the Mapuche struggle were staging frequent protests in Santiago. In November 2018 the Plaza Italia - the historical and symbolic border between the wealthy eastern sectors of the city and the poorer western districts - regularly filled with hundreds of protesters demonstrating against the police killing of the Mapuche comunero Camilo Catrillanca and subsequent cover-up. Further west along the central downtown thoroughfare, police repressed secondary school student protesters with water cannon and tear gas. ${ }^{28}$ The repression was nothing new: the public authorities have long curbed protests by people who challenge social hierarchies from positions of relative disadvantage, considering them threats to be suppressed rather than citizens to be served.

The elite perhaps has much to fear from a viable challenge to the neoliberal status quo. In the post-dictatorship era, even as poverty levels have improved, inequality has remained high: the bottom 50 per cent of the population possesses 2.1 per cent of national wealth, while the top 10 per cent captures 66.5 per cent, of which the top 1 per cent owns 26.5 per cent. ${ }^{29}$ Economic analysts also point to low social mobility within and across generations. This suggests that the accumulation of wealth at the top will persist as the current elite's descendants inherit the wealth and the privileges that accompany it, including material benefits and social, cultural and political power. Among those who do not enjoy such privilege, a 2017 
United Nations Development Programme study of inequality in Chile reported widespread experiences of 'systematic mistreatment, mistreatment at work, mistreatment by the wealthy, mistreatment in the streets' ${ }^{30}$ The Chilean Instituto Nacional de Estadísticas (INE)'s Encuesta Suplementaria de Ingresos (ESI) 2018, found that in 2018 half of Chilean workers earned CLP\$400,000 (USD\$600) or less per month. Nationally, the average salary was CLP\$573,964 (USD\$860), with marked gender-based salary disparities. ${ }^{31}$ Debt payments ate up, on average, 75 per cent of households' disposable income. ${ }^{32}$

While these numbers do not represent a sudden shift from earlier trends, although poverty and social inequality are plain to see in Santiago's streets, and likewise street protest had been on the rise for years prior to the October 2019 estallido social (social explosion), wealthy public figures expressed shock and fright as the 2019 protests increased in ferocity and momentum. Television personality Mario Kreutzberger (Don Francisco of Sábado Gigante) tearfully admitted his ignorance of people's fraying patience with social conditions, 'I realized there was a great deal of frustration, but I didn't know there was such rage and that there's an important human group that needs to be heard. ${ }^{33}$ First Lady Cecilia Morel commented in leaked audio that 'It's like a foreign invasion, alien [invasion]', and that 'we'll have to reduce our privileges and share with the rest' ${ }^{34}$ Morel's othering and dehumanization of people of lower socio-economic standing - 'foreign', 'alien' - is an historical pillar of elite social attitude in Chile that often emerges in unvarnished form when the 'masses' challenge the status quo. The elite know the neoliberal system favours them and have worked to naturalize the hierarchies of the socio-economic order in a self-justifying loop. During the dictatorship and the decades following the return to civilian rule in 1990, the elite-dominated government and mainstream mass media bombarded Chileans with the idea that consumer choice equals democracy, that the measure of a person's worth resides in their power to consume and that poverty is a personal, not structural, failure. ${ }^{35}$ These cultural attitudes have concrete results for access to opportunity and social mobility: they perpetuate neoliberal ideology and empower classist discrimination, a social ill with a long history in Chile and elsewhere.

Less privileged members of society have long been aware of this discourse and dynamic and have internalized it to greater or lesser extents, from buy-in to outright rejection. ${ }^{36}$ In the late 1970s and early 1980s, at the dawn of Chile's neoliberal era, the stark levels of social inequality the new system generated became apparent to residents of Santiago's poblaciones who watched luxury high-rises and conspicuous consumption proliferate in wealthier areas of the city as they and their children went hungry. By the twenty-first century, poverty levels had fallen but grinding precarity, persistent socio-economic inequities, deeply entrenched classism and an increasingly disconnected professional political class had soured popular appraisals of neoliberal democracy's ability to generate opportunity for those who were not already wealthy.

In addition to these and other long-standing grievances, during the 2010s government corruption scandals proliferated. While the right was no stranger to corruption scandals, it was becoming increasingly apparent that some affiliates of the Concertación had also taken advantage of the illicit opportunities that power offers those who lack moral and ethical fibre. A flood of corruption revelations splattered the professional political class and fed a growing sentiment among citizens that they'd been had and that the entire political class was irredeemably tainted. By the late 2010s a new narrative had emerged into mainstream public discourse: for years the dictatorship's old fans and enemies both had been profiting behind the backs of the pueblo, and these newfound neoliberal frenemies had despoiled the promise of the new democracy. Faced with protesters who refused to back down even in the face of the military, Piñera reversed the transport fare increase. This, too, failed to calm the waters. 'It's not 30 pesos', protesters responded, 'it's 30 years'. ${ }^{37}$

\section{Or is it 50 years?}

Chile's last experience of democracy, before the dictatorship and its imposition of the neoliberal model, was President Salvador Allende's Popular Unity (UP) government (1970-3). After the end of the dictatorship, socialist values regained little traction in a society still reeling from the effects of seventeen years of mass repression, structural adjustment and neoliberal social engineering. The political, economic and cultural environment cultivated during the dictatorship and strengthened after 1990 promoted 
individualism, consumerism and the internalization of personal blame for failure to thrive within an economic structure dependent upon the impoverishment of the many to the benefit of the few. And yet, the UP and its ideals did not die with the coup. The political coalition itself, anchored by the Socialist and Communist Parties, continued until 1981, when the parties shifted strategies. Collective memories of the UP's potential and the gains marginalized social sectors made during the Allende administration have outlasted Allende's government (1970-3), the UP political coalition (1969-79), the Pinochet dictatorship (1973-90) and 30 years of neoliberal democracy (1990-2020). People have passed these ideals from generation to generation despite the 17 years of dictatorship that sought to uproot them and the subsequent 30 years of neoliberal democracy in which policymakers and politicians studiously avoided even Keynesian alternatives to the modelo. ${ }^{38}$

The history and ideals of democratic alternatives to the neoliberal model survived underground, in individual memory, human rights associations, marginalized political collectives, activist circles, private households and exchanges between parents, children and grandchildren. ${ }^{39}$ During the dictatorship, when speaking of such things was dangerous, parents and elders quietly socialized young people in ethics and social values contrary to the violent, atomized world of dictatorial, neoliberal Chile. In transnational debates and clandestine meetings within Chile, the left critiqued the UP's shortcomings and revalued the importance of democratic ideals. The Catholic Church, left-wing political parties, community organizers and the social organizations in which they participated (e.g. community soup kitchens, workers' committees, Christian base communities, youth groups, cultural groups and the like) created spaces where children, youth and elders could work together in social and political solidarity. These became spaces where opposition to the dictatorship and alternative visions for society took refuge and passed to new generations. ${ }^{40}$

Intergenerational transmission of ethics and values contrary to the neoliberal status quo continued into the twenty-first century as the dictatorship's long shadow lingered. In the Chilean winter of 2000, I was at Salvador Allende's mausoleum in Santiago's General Cemetery when a woman appeared with her young son. The child climbed onto the monument's dais and began to read out loud the commemorative plaque engraved with words from Allende's last address to the nation:

Workers of my fatherland, I have faith in Chile and its destiny. Other men will overcome this grey and bitter moment in which treason seeks to prevail. Go forward knowing that, sooner rather than later, the great avenues again will open through which free men walk to build a better society. ${ }^{41}$

When the boy's reading faltered, his mother prompted him from memory. A few years later, at an outdoor community event in a población in southern Santiago, multiple generations shared the stage and watched from the audience. Acts included folk musicians performing Nueva Canción covers from the 1960s and 1970s, children dancing cueca (a traditional folk dance) and teenage hip-hop artists whose lyrics delivered incisive political critique of contemporary society. Such instances of transmission of alternative ideas across generations - in both directions - were not uncommon in local spaces. Below the surface of mainstream status-quo appearances, critique of post-dictatorship power structures and visions of a more just society circulated among generations.

Nearly two decades later, on 22 October 2019, as night-time curfew fell on Santiago, Víctor Jara's 1971 song 'El derecho de vivir en paz' (The Right to Live in Peace) echoed through the capital. In some neighbourhoods, protesters accompanied it with resounding caceroleo. Downtown, workers lit up the historic Teatro Municipal, set out loudspeakers and sent the song soaring through the empty streets. ${ }^{42}$ On 25 October 2019, the 'Mil guitarras para Víctor Jara' collective performed the song for enthusiastic crowds on the steps of the Biblioteca Nacional. ${ }^{43}$ Demonstrators rapidly adopted the song to protest state repression and emphasize their peaceful intentions. The use of 'El derecho de vivir en paz' as an anthem of peaceful protest was, on one level, incongruous because the song is about Vietnam's struggle against imperialist aggression. Taken in historical context, it alludes to transnational solidarity with armed resistance to oppression. Musicians quickly updated the lyrics for 2019, removing references to Ho Chi Minh and Vietnam and highlighting the domestic context: 'the right to live without fear, in our country', and 'respect and liberty, a new social pact, dignity and education, an end to inequality'. ${ }^{44}$ 
Music became a notable feature of mass demonstrations in the capital. On 27 October 2019, 500 orchestral and choral musicians gathered in Santiago's Plaza Bernardo Leighton, named after the Christian Democrat opponent of the dictatorship who in 1975 survived an assassination attempt by Pinochet's secret police. There, the musicians performed Mozart's 'Requiem' in condemnation of police brutality and in solidarity with the protesters. The second part of the concert included a dramatic rendition of the musical group Quilapayún's 1973 'El pueblo unido jamás será vencido' (The People United Will Never Be Defeated) with the audience singing along. ${ }^{45}$ On 13 December 2019, a multitudinous crowd spilling into the avenues surrounding the newly baptised Plaza de la Dignidad (ex-Plaza Italia) again held a mass sing-along of 'El pueblo unido'. Led by musicians of the iconic group Inti-Illimani, thousands sang this anthem of the UP and resistance to the dictatorship. The lyrics of 'El pueblo unido' are at once a celebration of existing unity, a call to broader and stronger unity and a warning to opponents that the pueblo plays the long game. Beyond its explicit reference to socialist revolution, 'the light of a red dawn announces the life to come,' most of the song focuses on the necessity of collective struggle to forge happier lives: 'On our feet, singing, we're going to triumph; banners of unity advance; you'll march together with me; and so you'll see your song and your banner flourish' ... 'On our feet, fighting, the pueblo will triumph; the life to come will be better; let's win our happiness.' The chorus, 'The people, united, will never be defeated!', offers a point of musical convergence for all to participate, regardless of whether they know the rest of the lyrics. In 1973, the song sought to counteract polarization and divisiveness among pro-UP sectors as oppositionist aggression mounted. Following the coup, it became a defiant call to unified resistance against the dictatorship. Today, the lyrics evoke this ongoing dynamic of struggle and hope, emphasizing the importance of unity and collective action to societal well-being.

In addition to music harking back to the UP, protesters adopted songs associated with the national protests of the 1980s. During the largest concentration of all, protesters sang Los Prisioneros' 1986 protest rock anthem 'El baile de los que sobran' ('The Dance of the Left-Over Ones'). ${ }^{46}$ This song speaks to the experiences of popular-sector youth who, upon graduation from secondary school, find themselves shut out of further educational and career opportunities: 'They taught others secrets they didn't teach you; they truly gave others this thing called education; they asked for effort, they asked for dedication; for what? To end up dancing and kicking stones.' The song invites everyone to join them in the dance. With historically relevant music and demonstrations in symbolic locations, the phantoms of democratic and socialist revolution and post-coup resistance materialized alongside present-day demands for change as the pueblo filled the grandes alamedas (great boulevards) of Allende's final speech. The protesters of 2019 evoked legacies of struggle whose incomplete reckonings lie just below the surface, despite politicians' repeated attempts to turn the page on the past. ${ }^{47}$

\section{Histories of protest culture}

Since the early nineteenth century, periodic 'social-citizen' movements have shifted the political course of the Chilean republic, and social movement and protest have been a central dynamic of historical change. ${ }^{48}$ Historically, Chilean political culture and practice have included both peaceful and non-peaceful protest. Peaceful mass demonstrations generally take place in public thoroughfares - the grandes alamedas - or large outdoor venues like the Parque O'Higgins. Whether for or against the government of the moment, these types of concentrations often tend to be politically pluralistic, multigenerational affairs. In addition, groups pursuing specific interests have long used peaceful protest tactics. Students, workers, women, campesinos, pobladores (residents of poblaciones), indigenous rights activists, human rights activists and supporters of various political candidates and positions have all engaged in peaceful demonstrations to further their causes. Most immediately, the mass demonstrations of 2019 recalled the peaceful protests of the dictatorial 1980s and the Popular Unity years. ${ }^{49}$ A notable, and unusual, characteristic of the 2019 protests was the lack of an identifiable lead organization or unified protest command. The various social organizations, local committees and political collectives that joined together in protest may have had organizational structures, but the protests themselves were a relatively horizontal, collective endeavour. ${ }^{50}$

Also in 2019, beyond the epicentres of mass peaceful protest in the Plaza de la Dignidad and the Plaza Ñuñoa, along small streets and in neighbourhood plazas, intergenerational groups of neighbours and social 
collectives drew on another thread of political-cultural legacy: they held local protest demonstrations and cultural activities, organized collective meals (ollas comunes) and participated in grassroots cabildos (councils) and assemblies to discuss visions for change. These forms of collective action also have a long history that predates the UP period. These smaller spaces and instances of human connection and endeavour are also - and perhaps principally - where democracy happens. This is where democratic ideals survive dark times, take root and grow. The adoption of deeply rooted forms of peaceful collective action, in symbolic locations with cultural touchstones, entwined past struggles with the present. In these and other ways, the protesters of 2019 invoked intergenerational memories and methods to dissent from the current neoliberal model, expressing a popular historicity that does not disassociate the past 50 years from the present and has not turned the page on the past.

Non-peaceful protest is as much a part of Chile's historical legacy of protest culture as its peaceful counterpart. ${ }^{51}$ Non-peaceful protest, which the Piñera administration condemned and international media outlets seemed to find both disturbing and disproportionately photogenic, was another notable aspect of this protest cycle. The burning barricades and masked youth confronting police recalled the 1980s: an era of furious rebellion when a massive, multisectoral cross-section of people, sick of economic misery, dictatorship and abuse, rose up against unsustainable political and economic conditions. ${ }^{52}$ Non-peaceful protest methods, which may include violence against people and property, have deep historical roots in Chile but became especially widespread and culturally familiar in the 1980s as pobladores protested against the dictatorship. Since 1990, these methods continued in the popular sectors and among university students and some leftist collectives, often on historically significant dates such as 11 September and 29 March. ${ }^{53}$ On these dates, images of burning barricades in Santiago's poblaciones and adjacent avenues, masked protesters with home-made defences, selective property damage and confrontations with the police filled national news media.

Non-peaceful protest has long met with government and media discourse about 'violence' and 'vandalism' in a dominant political culture that conflates violence against property with violence against people. ${ }^{54}$ This was a marked tendency during the dictatorship as the regime sought to criminalize protest of any kind. It continued in the post-dictatorship years as the Concertación disinherited the popular-sector protesters whose mass demonstrations of discontent during the $1980 \mathrm{~s}$ - not all of which were peaceful - opened a path to political transition. The Concertación forcefully propagated the myth of a peaceful transition to democracy, won at the polls with the power of the pen, in the interest of reinforcing 'governability' and delimiting the boundaries of citizen participation and political mobilization. ${ }^{55}$ In 2019 , these well-worn tropes created a feedback loop with the government's campaign to criminalize protesters in general, and non-peaceful protesters specifically, as delinquents, foreign agitators and enemies of the nation. ${ }^{56}$ In the context of rising unrest, mainstream media brandished provocative questions about protest, structured around misleading categorizations such as 'Mass [fare] evasion: just[ified] complaint or vandalism?' that attempted to redirect public attention from core issues and into false dichotomies. ${ }^{57}$ The propriety of a protest method does not establish the legitimacy of the complaint: a protest method can be inappropriate, and the complaint can still be just. For example, on the night of 18 October, the saqueo (sacking) of pharmacies and commercial establishments such as Líder (Walmart) and the destruction of metro stations in poorer areas of the capital, contributed to escalating public fears of social unrest, destruction of property and lawlessness. ${ }^{58}$ In Chile sacking garners generalized public condemnation as an inappropriate activity. Yet, as the historian Mario Garcés notes, these incidents of sacking can be interpreted as attacks on symbols of capital and the state, with which people have deeply legitimate complaints. ${ }^{59}$ Debates over the legitimacy of protest methods came further into focus as the protests expanded to include multiple repertoires of dissent with varied historical and social roots.

In the popular sectors as well as downtown, peaceful and non-peaceful protest methods often unfold in geographic and temporal proximity to one another, and 2019 was no exception. During the 1980s, the young protesters who built, tended and defended the barricades in their poblaciones did so to express dissent and to deter state security forces from entering the neighbourhoods. They simultaneously made a political point by staking out and controlling a defined territory. Their territorial control was largely symbolic - there was a vast power differential between the protesters and state security forces. Yet, during 
protests, the barricades and their guardians created a temporary buffer between the state security forces and peaceful protesters behind the front lines who held marches, ollas comunes and cultural activities. ${ }^{60}$ Since the 1980s, protest methods involving burning barricades, masked protesters, confrontation with the police and selective property damage have become a traditional part of protest culture within, and beyond, Santiago's poblaciones.

As the Plaza de la Dignidad became the epicentre of protest activity, by mid-November 2019 another protest actor appeared in the form of the Primera Linea (Front Line). The masked Primera Línea protestors symbolically demarcated the limits of the repressive state's power and challenged the 'legitimate violence' of the state, by blocking the streets leading into the plaza and mounting defence with home-made shields and a willingness to fight the police. ${ }^{61}$ The presence of encapuchados (hooded ones) in protests, marches and cultural activities downtown was not new. Around the turn of the twenty-first century, anarchist collectives grouped in casas okupa (squats) met with increasing state repression as anarchists became the new political bogeymen of the post-cold war metropolis. ${ }^{62}$ Associated with anarchists in popular imagination or in fact, during the mid- to late 2000s encapuchados would emerge at the tail end of peaceful protests to confront the police. The police often provoked confrontations by attacking first, and the conflicts escalated quickly; the encapuchados also in some instances engaged in what appeared to be indiscriminate property damage. In turn, successive governments used the encapuchados' existence as justification to repress and criminalize street demonstrations more broadly. The encapuchados' methods ultimately earned the opprobrium of the various organizations that would convoke and participate in marches; these increasingly tried to discourage the encapuchados from attaching themselves to peaceful demonstrations and publicly disassociated themselves from them.

In 2019, when the protesters who became known as the Primera Línea appeared near the Plaza de la Dignidad, the irruption into the downtown scene of methods long associated with Santiago's poblaciones and with the encapuchados of the earlier twenty-first century aroused consternation. It also represented what could be described as an encounter between class-based protest cultures. Although peaceful protest is part of popular-sector political culture and the poor and working classes have made ample use of peaceful protest methods for over a century, in Chilean political culture peaceful protest is often associated with the middle and professional classes, while non-peaceful protest is most often associated with the poor and working classes. ${ }^{63}$ Historically, the poor and working classes have perhaps employed a broader repertoire of protest methods, given the circumstances they protested and the repression they faced. The use of confrontational protest methods in poblaciones during the national protests of the 1980s and the continuance of those protest methods into the post-dictatorship period, as well as media emphasis on violent popular-sector protest and failure to cover peaceful protest in the same neighbourhoods, has likely contributed to reproducing and reinforcing these associations. ${ }^{64}$ Indeed, as the scholars María Eva Muzzopappa and Alicia Salomone have indicated, early mainstream media reports about the Primera Línea suggested that they represented 'vandalism or violence in its pure state, as an anomic action that sought to destabilize and/or destroy the social order, detaching itself from agreements that could produce progressive changes' ${ }^{65}$

The encapuchados of the Primera Línea engaged in physically combative, non-peaceful protest. They formed barriers, blocked vehicular access to certain territories (like the Plaza de la Dignidad), threw rocks and sometimes Molotovs, damaged property and fought the police. Yet, over time, unlike the encapuchados of the earlier twenty-first century, the Primera Línea became an accepted part of the broader social movement. As police repression intensified and horrifying human rights violations mounted, the Primera Línea's defensive stance against the police and protection of peaceful protesters accumulated even more symbolic power. Primera Línea pop-culture superheroes emerged in comics, memes and street art. One was a black dog wearing a red bandana, baptised 'El Negro Matapacos' (Matapacos means cop-killer), who had joined university students in the 2011 protests and became famous for fighting alongside them against the police. ${ }^{66}$ A second superhero, born of the 2019 protests, was PareMan (Stop Man). PareMan originated in viral photographs of a masked protester using a traffic stop sign as a shield against the police. ${ }^{67}$ The Primera Línea gained acceptance by enacting an ethics of violence that obeyed codes and logics contrary to those of the police, who were increasingly viewed as exercising illegitimate, 
indiscriminate and disproportionate violence. The Primera Línea also distanced itself from practices associated with the encapuchados of yore: they engaged in violent confrontation with the police, but they did this to allow peaceful protests to take place, helping people exercise their legitimate right to protest. ${ }^{68}$

This symbiotic relationship was suggestive of the national protests of the 1980s in poblaciones. There, non-peaceful protest followed certain parameters, and protesters distinguished between legitimate and illegitimate use of violence based on assessments of context and just intent. For example, violence in self-defence was both just and legitimate, especially against the more powerful forces of state repression that had delegitimized themselves by violating human rights. In terms of property damage, damage to public property (e.g. paving stones, street signs, materials useful for building barricades) was considered just and legitimate in the context of protecting human bodies from potentially lethal police violence. Violence against passers-by, peaceful protesters and neighbours, or deliberately damaging private property, were neither just nor legitimate. ${ }^{69}$ That an ethics existed did not mean that it was inviolate or universally respected. Nevertheless, violent popular-sector protest during the national protests of the 1980s was not characterized by disorganized chaos. Nor was the Primera Línea. What, if any, direct historical links might exist between these times, places and protesters is not clear. That the Primera Línea channels these historical legacies of protest does not mean that its members are only or primarily from poblaciones combative protest in poblaciones has been broadcast in the national media since at least the 1980s. What we can say is that protest culture is learned, and protest methods are acquired knowledge. Like ideas and values, they are passed down through generations, and new generations adopt, adapt and build upon them.

These protests and protest methods are but a few examples of the ways that people enacted dissent in 2019. From mid-October and into the new year, millions of people mobilized in groups large and small to express discontent and hope as they confronted the legacies of decades using tools of protest, socio-political participation and direct democracy accumulated over the course of more than 50 years. In streets, plazas and neighbourhoods across the country, people employed a multiplicity of grassroots protest methods ingrained in popular history. In 2019, a new generation without the burdens of fear inherited from the dictatorship came to dominate the streets and plazas. Their elders were there with them, in person and in the reverberations of the past half-century of struggles for democracy.

\section{Epilogue}

The protests of 2019 met with increasing repression, including anti-protest legislation that Congress passed in December of that year. ${ }^{70}$ As is usually the case in Chile, protest activity ebbed over the new year and through February, as the holiday season and summer vacation months changed social and political rhythms. In March 2020, street protest was on the rise again until the COVID-19 pandemic ground the capital, and much of the rest of the country, to a halt. ${ }^{71}$ As the public health crisis spread, the government postponed the constitutional plebiscite from April to October 2020. In the popular sectors, neighbourhood activists started up ollas comunes to alleviate hunger as closures and mandatory stay-at-home orders left people without income. Youth collectives, still organized from the protests, mobilized to sanitize bus stops and provide other community services.

As the virus burned through Chile, discontent simmered as the authorities mismanaged the public health crisis and already strapped household economies cracked under the financial strain. When lawmakers balked at a proposal to allow people to withdraw 10 per cent of their retirement savings from their private pension fund administration (AFP) accounts, protesters returned to the streets and caceroleo rang out across the country. ${ }^{72}$ In mid-August, the president of the Colegio Médico, Dr Izkia Siches, emphasized the importance of implementing the public health measures necessary to carry out the plebiscite in October: 'We call [on the government] to not use the pandemic to inhibit participation, and to work tirelessly to guarantee everyone's participation. Democracy cannot succumb to this pandemic. ${ }^{73}$

This most recent chapter of social struggle for change that opened with the 2019 protests is still ongoing. Protest activity and police repression resurged in the Plaza de la Dignidad on the first anniversary of 18 October 2019 and on the eve of the constitutional plebiscite. On 25 October 2020, Chileans overwhelmingly voted in favour of writing a new constitution (78 per cent) via a constitutional convention (79 per cent). Elections for delegates to the constitutional convention are scheduled for 11 April 2021. ${ }^{74}$ 
In the meantime, popular pressure and protest continues in an effort to hold the state accountable for human rights violations, to secure the release of people imprisoned for protest activities and to ensure that the political and economic elite does not co-opt the constitutional convention. A new constitution is not the movement's endgame, nor is democratization solely bound by formal political procedure. The pandemic has created hurdles and complications, but the vast social movement that coalesced in 2019 and the people, legacies and dreams that fuel it live on.

\section{Declarations and conflict of interests}

The author declares no conflict of interest with this work.

\section{Notes}

All translations from Spanish by the author.

${ }^{1}$ The first time since 1987. States of emergency, curfews and military mobilization have been used since 1987 in the aftermath of natural disaster, most notably in the southern city of Concepción after the 2010 earthquake. This met with various levels of acceptance, distrust and concern. Rojo, 'Saqueos' and Garcés 'Terremoto natural y terremoto social en Chile'. On the militarization of politics in Chile dating back to the 1940s, see Valdivia, 'Recobrando la democracia'.

${ }^{2}$ An analyst at the Universidad Diego Portales calculated that Santiago's public transport system was the ninth most expensive in the world relative to median income. Ferrer, 'Estudio ubica a Santiago en el top 10 del ranking del transporte público más caro en función del ingreso medio'.

3 “"En Chile algunos han perdido el humor".

${ }^{4}$ On 18 October 2019 a reporter for the mainstream, traditionally conservative Canal 13 asked a woman passer-by whether she thought protesting via mass fare evasion in the metro was 'just[ified] complaint or vandalism?' She replied with an exegesis of the socio-economic situation in neoliberal Chile that quickly went viral in which she explained, among other things, that 'if a person spends 50,000 pesos per month on transport, he can't eat. That's the grocery money'. See: “'Si una persona gasta $\$ 50.000$ en locomoción no puede comer"'.

${ }^{5}$ See, for example, Jara Román, Piñera y los leones de Sanhattan. For the relationship between human rights violations and concentration of wealth in Chile, see Fernández et al., Complicidad económica.

${ }^{6}$ Garcés, Estallido social, Loc. 57-61.

7 “"La peor crisis de DD.HH. desde la dictadura"'.

8 “"La peor crisis de DD.HH. desde la dictadura"; Garcés, Estallido social, Loc. 1019; Naciones Unidas, Oficina del Alto Comisionado de Derechos Humanos, 'Informe sobre la Misión a Chile'; and Instituto Nacional de Derechos Humanos (INDH), 'Informe Anual'; Organización de los Estados Americanos (OEA), Comunicado de Prensa, 'CIDH condena el uso excesivo de la fuerza en el contexto de las protestas sociales en Chile'.

9 “"La peor crisis de DD.HH. desde la dictadura"'.

${ }^{10}$ Winn, 'The Furies of the Andes', 263.

${ }^{11}$ See Lira and Loveman, El espejismo de la reconciliación política; Lira and Loveman, Políticas de reparación, Chile 1990-2004; and Wright, Impunity, Human Rights, and Democracy.

${ }^{12}$ Andrews, 'Presidente Piñera: "Estamos en guerra contra un enemigo poderoso"”.

${ }^{13}$ See, for example, 'Piñera: "He recibido información que afirma que aquí hubo intervención de Gobiernos extranjeros"'; Flores, 'Piñera apunta a odio y violencia en el Congreso y desata críticas desde la oposición'; 'Piñera dice que muchos de los videos sobre violaciones a los DDHH divulgados durante crisis "son filmados fuera de Chile"'; Gobierno de Chile, 'Presidente Piñera anuncia conjunto de propuestas para una nueva agenda social'; 'Gobierno contrató campaña publicitaria "por la paz” por \$202 millones'; 'Sebastián Piñera y equivocaciones durante estallido social'.

${ }^{14}$ For a summary, see Salazar, En el nombre del poder popular constituyente and Garcés, El despertar de la sociedad. Both of these books came out in the context of the 2011-12 university student protests. On the secondary student protests of 2006 see Domedal and Peña y Lillo, El mayo de los pingüinos. For 
the university student protests of 2011, see Figueroa, Llegamos para quedarnos and Garcés Sotomayor and Santa Cruz, "El parto de un nuevo ciclo político".

${ }^{15}$ Garcés, Estallido social, Loc. 830.

${ }^{16}$ Garcés, Estallido social, Loc. 830.

${ }^{17}$ Larrondo, 'Chile el país más feliz de Sudamérica'.

18 'Presidente Piñera: Chile es un verdadero oasis en una América Latina convulsionada'. Ariel Dorfman took Piñera and the ruling class to task as the protests and repression belied the 'oasis' boasts, in Dorfman, 'Adiós al oasis chileno'.

${ }^{19}$ In Estallido social, historian Mario Garcés explains saqueo (looting or sacking) of metro stations, commercial retail and grocery outlets such as Líder (Walmart), and pharmacies that occurred during the 2019 unrest as not just an expression of anomie and violence but rather a mixture of spontaneous and targeted popular-sector violence against symbols of the state and private capital - two cornerstones of the neoliberal system (Loc. 144-56, Loc. 164, Loc. 452-6, Loc. 535). Rising transport prices and also rising prices for basic necessities and pharmaceuticals may have shaped the choice to target stores like Líder and commercial pharmacies. Garcés identifies three likely participants in these incidents, not necessarily at the same time or in concert with one another: young people from low-income popular-sector neighborhoods (poblaciones), small groups of militant youth, and young soldados of narco-trafficking networks (Loc. 73, Loc. 535). Saqueo is not a new element of social unrest in popular-sector Chile. It is, though, a delicate topic in that the chain of events (who, why, etc.) is often unclear, and both the government and mainstream media tend to seize upon these incidents of violence against property to criminalize protest more generally and justify repression.

${ }^{20}$ Bruey, interviewed by Jaffee, Civil Discord, Episode 7.

${ }^{21}$ Michael Denning argues that democracy 'is neither [US] American nor capitalist, but is the social movement that fought for and created the democratic institutions of the state and civil society that we have [...] the democracy remains the social movements that fight to preserve and extend those democratic institutions'. Denning, 'Neither Capitalist nor American: The Democracy as Social Movement', 210-11.

${ }^{22}$ The Concertación, anchored by the Christian Democrat Party and renovated (capitalist) Socialists, had held the executive branch from 1990 to 2010, and again from 2014 to 2018, the latter period under the name Nueva Mayoría with the inclusion of the Chilean Communist Party and other left-wing parties. The right-wing Alianza (later, Chile Vamos) coalition, anchored by Renovación Nacional (RN) and the pinochetista Unión Democrática Independiente (UDI), despite not holding executive office during those years, held a significant quota of power at the legislative, judicial and municipal levels. From 2010 to 2014 and from 2018 to the present, Sebastián Piñera (RN) has been president. The formation of the left-wing Frente Amplio (which included leaders of the 2011-12 university student protests), had little effect on power structures. In December 2019, Frente Amplio congresspeople by and large either voted for or abstained from voting on repressive anti-protest legislation. Garcés, Estallido social, Loc. 958. For post-1990 party politics, see Angell, Democracy After Pinochet and Álvarez, 'El largo camino de la izquierda chilena'.

${ }^{23}$ Álvarez, 'El largo camino de la izquierda chilena', 63-65; Bruey, Bread, Justice, and Liberty, 39-40.

${ }^{24}$ Bachelet's family history was largely responsible for this symbolism as was her work, as a pediatrician, with children who had suffered human rights abuses during the dictatorship. She cultivated a constructive working relationship with grassroots human rights collectives, and, during her first administration, memorialization projects took off. This process culminated in the opening of the Museo de la Memoria y los Derechos Humanos in 2010. Stern and Winn, 'El tortuoso camino chileno a la memorialización', 245, 247. This does not mean, though, that her presidency ran to the left of the Concertación.

${ }^{25}$ See Ley $\mathrm{N}^{\circ} 20.840$ (2015), 'Sustituye el sistema electoral binominal por uno de carácter proporcional inclusivo y fortalece la representatividad del Congreso Nacional', Biblioteca del Congreso Nacional de Chile, https://www.bcn.cl/historiapolitica/elecciones/detalle_eleccion?handle=10221.1/63227\&periodo= 1990-2022. Around the time that Bachelet won the 2013 presidential primary and launched her second presidential campaign, a book questioning the modelo and proposing a bevy of reforms caused a stir in Santiago: Atria et al., El otro modelo. 
${ }^{26}$ See Gálvez, 'Historia del movimiento feminista en Chile', and Zerán, ed., El mayo feminista.

${ }^{27}$ See for example Correa and Mella, Las razones del illkun/enojo; Pairican, 'La gran revuelta Mapuche 1990-2010'; and Illanes, “"Water rights for sale"”.

${ }^{28}$ I witnessed the protests and repression in the Plaza Italia because they occurred along the route of my daily evening commute and in clear view of my apartment window. For an example of international news reporting on these protests, see, for example, Bonnefoy, 'Killing of indigenous man in Chile spurs criticism of security forces'; and 'Chile: Four police officers arrested over fatal shooting of indigenous man'.

${ }^{29}$ INDH, 'Informe Annual', 7.

${ }^{30}$ Dante Contreras, quoted in Sepúlveda, ‘QQué tan desigual es Chile?’; Área de Reducción de Pobreza y Desigualdad del PNUD en Chile, Desiguales; and María Luisa Méndez and Dante Contreras, cited in Sepúlveda, '¿Qué tan desigual es Chile?'

31 'INE: La mitad de los trabajadores en Chile recibe un sueldo igual o inferior a $\$ 400.000$ al mes'. The highest average salaries were not in the capital city but rather in the regions of Antofagasta and Magallanes.

${ }^{32}$ Reyes, 'La deuda en los hogares chilenos sigue subiendo y equivale al 75\% del ingreso disponible'.

${ }^{33}$ Report on a discussion that occurred on Canal 13's show Bienvenidos, in 'Don Francisco lloró por la situación país'.

34 'La Tercera confirma que audio filtrado de Cecilia Morel es real'.

${ }^{35}$ See Lavín, Chile: Revolución silenciosa; Moulian, Chile actual; and Paley, Marketing Democracy.

${ }^{36}$ On right-wing politics in the popular sectors, see Valdivia Ortiz de Zárate et al., La alcaldización de la politica; on the uneven legacies of neoliberalism and the benefits it brought to some workers see Tinsman, Buying into the Regime.

${ }^{37}$ This became a call to protest. See, for example, Red de Historiadoras Feministas, ' No son 30 pesos, son 30 años!'

${ }^{38}$ The Popular Unity coalition and its ideals were not an historical anomaly that appeared out of nowhere in 1969. Its predecessor, the Frente de Acción Popular (FRAP) had run Allende for president three times before, and Chile had a long history of leftist activism and leftist democratic ideals since the late nineteenth century that included anarchists, socialists and communists. For influential critiques of Chile's neoliberal democracy, see Moulian, Chile actual. For its effects on workers and pobladores, respectively, see Winn, ed., Victims of the Chilean Miracle; Tinsman, Buying into the Regime; and Paley, Marketing Democracy. For recent analyses of contemporary Chilean democracy, dictatorial legacies and the transition see Tinsman, 'La democracia chilena', Ponce et al. eds., Transiciones, and Pinto, ed., Las largas sombras de la dictadura.

${ }^{39}$ On the persistence of memories, ideals and values across historical periods see Stern, The Memory Box of Pinochet's Chile Trilogy; Hite, When the Romance Ended; Schlotterbeck, Beyond the Vanguard, Epilogue; Garcés and Leiva, El golpe en La Legua; and Bruey, Bread, Justice, and Liberty.

${ }^{40}$ Bruey, Bread, Justice, and Liberty, chapters 4-6.

${ }^{41}$ Plaque, Allende Bussi family mausoleum, Cementerio General, Santiago de Chile, 2000. Author photo. The original reads: 'Trabajadores de mi patria, tengo fe en Chile y su destino. Superarán otros hombres este momento gris y amargo donde la traición pretende imponerse. Sigan Ustedes sabiendo que mucho más temprano que tarde, de nuevo se abrirán las grandes alamedas por donde pase el hombre libre para construir una sociedad mejor...'

${ }^{42}$ Lepe, 'El derecho de vivir en paz'; and 'Emocionante!!'

${ }^{43}$ Víctor Jara - Música, 'El derecho de vivir en paz - Biblioteca Nacional - Octubre 2019'.

${ }^{44}$ For the updated version, see Musicxs de Chile, 'El Derecho de Vivir en Paz (Video Oficial 2019)'.

${ }^{45}$ La Mura, 'Karin Friedli, soprano y parte del Requiem por Chile'; Alarcón L., 'Réquiem por Chile'; A smartphone video of the 'El pueblo unido' segment went viral on Facebook and was reported in Mexico's La Jornada, 'Orquesta toca "El pueblo unido, jamás será vencido!"' The orchestra reprised the performance in November 2019, at the Centro Cultural Gabriela Mistral (GAM), a significant building in downtown Santiago built during the UP to host the third United Nations Conference on Trade and Development (UNCTAD III) and repurposed after the coup to serve as the dictatorship's headquarters and 
Ministry of Defence. For a GAM performance video, see rojas, "El pueblo unido jamás será vencido" Víctor Jara Sinfónico'. For more on the importance of street protest and place during the UP period that includes the GAM, see Trumper, Ephemeral Histories. In the following months, the orchestra travelled to various sites in Santiago and Valparaíso to perform the Mozart concert. For the orchestra's performance of Violeta Parra's 'Qué dirá el santo padre' in Plaza Salvador Allende in población La Legua, an emblematic neighbourhood in working-class Santiago, see Ars Nova, 'Requiem por Chile - Qué dirá el Santo Padre de Violeta Parra en La Legua'.

46 'Protestas en Chile: "El baile de los que sobran".

${ }^{47}$ These legacies of struggle reach much further into the past than even 1970, but the most notably widespread cultural references evoked the past 50 years. An example of a much longer legacy of struggle, for women, appears in Las Tesis's viral protest-art action 'Un violador en tu camino' (A Rapist in Your Path). See Colectivo Registro Callejero, 'Performance colectivo Las Tesis "Un violador en tu camino".

${ }^{48}$ Salazar, En el nombre del poder popular constituyente; Salazar, La historia desde abajo y desde adentro; Illanes, Chile Des-centrado; Garcés, Crisis social y motines populares.

${ }^{49}$ On mobilization during the UP, see, for example, Winn, Weavers of Revolution; Pinto, ed. Cuando hicimos historia; Pinto ed., Fiesta y drama; Schlotterbeck, Beyond the Vanguard.

${ }^{50}$ Raúl Zibechi discusses horizontal tendencies in post-Cold War Latin American social-movement organizations. Zibechi, Territories in Resistance.

${ }^{51}$ On the longer historical roots of popular-sector protest, peaceful and otherwise, see, for example, Garcés, Crisis social y motines populares en el 1900; Milos, 2 de abril de 1957; Salazar, La violencia politica popular en las 'Grandes Alamedas'; Craib, Cry of the Renegade; Schlotterbeck, Beyond the Vanguard; and Bruey, Bread, Justice, and Liberty.

${ }^{52}$ Bruey, Bread, Justice, and Liberty, chapter 6.

${ }^{53}$ These correspond to the date of the coup and the Día del Joven Combatiente that commemorates the lives and political assassinations of the young Movimiento de Izquierda Revolucionaria (MIR) militants Eduardo and Rafael Vergara Toledo in 1985. During the 1980s, especially, anti-regime resistance between pobladores and university students, university students who were also pobladores, formed in some areas of Santiago.

${ }^{54}$ Winn, 'The Furies of the Andes,' 259, 273-4; and Bruey, Bread, Justice, and Liberty, 170-3.

${ }^{55}$ For the demobilization of social movements after 1990, see Paley, Marketing Democracy and Garcés, 'Los movimientos sociales en la transición'.

${ }^{56}$ This is, in turn, a traditional government response to social unrest. For examples from 2019, see 'Sebastián Piñera advierte que manifestantes tienen la logística de "una organización criminal”"; 'Piñera: "Estamos en guerra contra un enemigo poderoso",; 'Presidente Piñera: "Sabemos perfectamente bien qué están preparando para mañana"; "Gobierno insiste en tesis de la "influencia extranjera" pese a cuestionado informe de Big Data'; and 'Duro rechazo a declaraciones de Piñera donde acusa que imágenes de violaciones a DD.HH. son grabadas en el extranjero'.

${ }^{57}$ This question was part of Canal 13's morning show, Bienvenidos, in which a reporter interviewed commuters near the Plaza Maipú metro station about the fare hike protests in metro stations. The rhetoric displayed in this formulation of the debate is representative of common approaches to public debate about protests and social unrest. The 'just[ified] complaint or vandalism' question appeared as a chyron for the TV-viewing public to consider. A screenshot is available in “'Si una persona gasta $\$ 50.000$ en locomoción no puede comer"'.

${ }^{58}$ For an analysis of saqueo, see Garcés, Estallido social. On 20 October, the Metro reported damage to six trains and 77 of Santiago's 136 metro stations. The most severe damage occurred at stations in popular-sector Santiago: Los Quillayes, San José de la Estrella, Trinidad, Protectora de la Infancia, Elisa Correa, La Granja, were 'completamente incendiadas' (completely burned). Metro de Santiago, 'Balance daños 19 de octubre 2019'. For a brief history of the Santiago metro and the urban transport context of the 2019 protests, see Chastain, 'The Santiago Metro as a Microcosm of Chile'.

${ }^{59}$ Garcés, Estallido social, Loc. 144-56, Loc. 164, Loc. 452-6, Loc. 535. 
${ }^{60}$ For more on the protests in poblaciones during the dictatorship, see Bruey, Bread, Justice, and Liberty, chapter 6; Garcés, Pan, trabajo, justicia y libertad, chapter III; and Schneider, Shantytown Protest.

${ }^{61}$ For an important discussion of public discourse about violence, legitimacy and the Primera Línea, see Muzzopappa and Salomone, 'Sobre la legitimidad de la violencia'.

${ }^{62}$ Prior to the anarchists were the remnants of the anti-regime armed left, grouped in the Frente Patriótico Manuel Rodríguez (FPMR) (-Autónomo, after 1988) and MAPU Lautaro. These organizations originally arose during the 1980s from the Chilean Communist Party (PCCh) and a segment of the Movimiento de Acción Popular Unitario (MAPU). For a history of Chilean anarchism in the 1980s and early 1990s, see Godoy, 'Una transición antes de la transición'.

${ }^{63}$ See, for example, Garcés, Estallido social, Loc. 164.

${ }^{64}$ In the sector of Villa Francia, where the Día del Joven Combatiente (29 March) has been a day of commemoration and protest for many years, well into the twenty-first century the media focused almost exclusively on the non-peaceful aspects of the day's events (burning barricades, property damage to the local COPEC petrol station, confrontation with police). The cultural activities, speeches and memorial marches very rarely appeared in the mainstream media reports.

${ }^{65}$ Muzzopappa and Salomone, 'Sobre la legitimidad de la violencia'.

${ }^{66} \mathrm{El}$ Negro Matapacos did not live to participate in the 2019 protests; he died of natural causes in 2017. The youth of the 2019 protests resurrected his memory and image. For a death notice that includes examples of street art, see Armand, "Murió el legendario "Negro Matapacos"'. For a documentary, see Ramírez, dir. Documental Matapaco. For images from the 2019 protest cycle, see 'Los homenajes gráficos al "Negro Matapacos"'. 'Riot dogs', as a cultural phenomenon, went viral during the Greek anti-austerity protests of 2008-11. Kanello and especially Loukanikos, two dogs that had joined street protesters in Athens, became famous. See Memmott, "'Riot dog” is back in Athens'; Stamouli, 'Loukanikos, the Greek protest dog, dies'; and 'Famous Greek riot dog Loukanikos dies'. 'Riot dogs' have long been present in protests in Santiago, but before El Negro Matapacos they lived and died in relative anonymity. Perhaps the 'riot dog' celebrity phenomenon spreading through transnational digital media circa 2008-11 played a role in the construction and propagation of El Negro Matapacos's celebrity in 2011-12 and 2019.

${ }^{67}$ See, for example, Arros, 'Pareman llega al cómic de la mano de KID Salinas'; and Twitter \#pareman and \#matapacos. For images of PareMan and El Negro Matapacos in the international media, see, for example, 'Los héroes de las protestas en Chile'. Pop icons of the 2019 protests also included a dancing Pikachu protester ('Baila Pikachu') and 'Estúpido y Sensual Spiderman' (Stupid and Sensual Spiderman) (a reference to a Simpsons episode). For an overview see "Negro Matapacos", "Pareman" y "Baila Pikachu": Los íconos del estallido social en Chile'.

${ }^{68}$ Muzzopappa and Salomone, 'Sobre la legitimidad de la violencia'.

${ }^{69}$ Bruey, Bread, Justice, and Liberty, 203. During the dictatorship in 'combative' poblaciones, local Catholic priests, nuns and laypeople in popular-sector Christian base communities were involved in discussions with young people about political violence and ethics, and the Church's Vicariate of Solidarity supported social organizations and provided legal aid. In 2019 the Catholic Church was conspicuous by its absence. The Church as an institution has lost legitimacy in the wake of sexual abuse and corruption scandals. Notable exceptions were ecumenical groups of protesters who demonstrated as Christians in the Plaza Italia, and the legendary Catholic worker-priest Mariano Puga, who supported the protest movement before passing away on 14 March 2020. Labrín, 'Jesús habría estado aquí'; and 'Mariano Puga por crisis en Chile'.

${ }^{70}$ In December 2019 the Senate took up a constitutional accusation against ex-Minister of the Interior Andrés Chadwick and found him politically responsible for violations of human rights during the state of emergency. He is prohibited from holding public office until 2024. Carvajal G., 'Senado inhabilita a Andrés Chadwick para ejecer cargos públicos por 5 años'.

${ }^{71}$ See, for example, Ramírez, 'Norte, centro y sur: cacerolazos a lo largo de Chile culminan primera noche de marzo'; and Valenzuela Sebik, 'Primera evasión masiva de marzo'. 
72 'REDESI \#CacerolazoPorMi10'. The measure passed. The private pension system is a profit machine for the pension companies, not the pensioners - many people saw little value in leaving their AFP accounts intact given these funds' miserable performance for pensioners thus far.

${ }^{73}$ Colegio Médico de Chile A.G., 'Presidenta de Colmed hace llamado al gobierno...'.

${ }^{74}$ Molina, 'Plebiscito en Chile'; and ‘¿Cuándo es la próxima elección en Chile y qué se vota?'

\section{References}

Aguilera, Silvia, ed. El Terremoto social del Bicentenario. Santiago: LOM, 2010.

Alarcón L., Rodrigo. 'Réquiem por Chile: conciertos gratuitos continúan en La Florida, Lo Hermida y La Legua'. Diario U Chile, 7 December 2019. Accessed 10 September 2020. https://radio.uchile.cl/2019/ 12/07/requiem-por-chile-conciertos-gratuitos-continuan-en-la-florida-lo-hermida-y-la-legua/.

Álvarez, Rolando. 'El largo camino de de izquierda chilena: ¿de la marginalidad política a alternativa de poder? (1988-2018)'. In Las largas sombras de la dictadura: A 30 años del plebiscito, ed. Julio Pinto, 59-90. Santiago: LOM, 2019.

Andrews, Juan Pablo. 'Presidente Piñera: "Estamos en guerra contra un enemigo poderoso"'. La Tercera, 20 October 2019. Accessed 10 September 2020. https://www.latercera.com/politica/noticia/ presidente-pinera-estamos-guerra-enemigo-poderoso/870658/.

Angell, Alan. Democracy after Pinochet: Politics, parties and elections in Chile. London: Institute for the Study of the Americas, 2007.

Área de Reducción de Pobreza y Desigualdad del PNUD en Chile. Desiguales: Orígenes, cambios y desafios de la brecha social en Chile. Santiago: PNUD, 2017.

Armand, Belén. 'Murió el legendario "Negro Matapacos"'. La Izquierda Diario, 27 August 2017. Accessed 10 September 2020. http://www.laizquierdadiario.cl/Murio-el-legendario-Negro-Matapacos.

Arros, Fernanda. 'Pareman llega al cómic de la mano de KID Salinas'. La Tercera, 8 November 2019. Accessed 10 September 2020. https://www.latercera.com/mouse/pareman-comic-guido-salinas/.

Ars, Nova. 'Requiem por Chile - Qué dirá el Santo Padre de Violeta Parra en La Legua'. 22 April 2020. Accessed 10 September 2020. https://www.youtube.com/watch?v=j_1JPiOHBA4.

Atria, Fernando, Guillermo Larraín, José Miguel Benavente, Javier Couso, and Alfredo Joignant. El otro modelo: Del orden neoliberal al régimen de lo público. Santiago: Random House Mondadori S.A./Debate, 2013.

Bonnefoy, Pascale. 'Killing of indigenous man in Chile spurs criticism of security forces'. New York Times, 25 November 2018. Accessed 10 September 2020. https://www.nytimes.com/2018/11/25/ world/americas/indigenous-killing-chile-land.html.

Bruey, Alison J. Bread, Justice, and Liberty: Grassroots activism and human rights in Pinochet's Chile. Madison: University of Wisconsin Press, 2018.

Bruey, Alison J., interview by David Jaffee, Civil Discord, Episode 7, 2 November 2019. Accessed 10 September 2020. https://civildiscord.podbean.com/e/civil-discord-episode-7/.

Carvajal G., Claudia. 'Senado inhabilita a Andrés Chadwick para ejecer cargos públicos por 5 años'. Diario U Chile, 11 December 2019. Accessed 10 September 2020. https://radio.uchile.cl/2019/ 12/11/senado-inhabilita-a-andres-chadwick-para-ejercer-cargos-publicos-por-5-anos/?fbclid= IwAR0PsOUDSIevOeHPVRf1PmP9tqA4yX-EN5uU5NX08MPjEfgX_rSAl2Q6ys8.

Chastain, Andra B. 'The Santiago metro as a microcosm of Chile'. NACLA, 30 October 2019. Accessed 10 September 2020. https://nacla.org/news/2019/10/28/santiago-metro-chile-protests.

'Chile: Four police officers arrested over fatal shooting of indigenous man'. Guardian, 29 November 2018. Accessed 10 September 2020. https://www.theguardian.com/world/2018/nov/29/chile-camilocatrillanca-death-four-police-officers-arrested.

Colectivo Registro Callejero. 'Performance colectivo Las Tesis "Un violador en tu camino"'. YouTube, 26 November 2019. Accessed 10 September 2020. https://www.youtube.com/watch?v=aB7r6hdo3W4.

Colegio Médico de Chile A. G. 'Presidenta de Colmed hace llamado al gobierno a entregar las máximas condiciones de seguridad para plebiscito en pandemia'. 19 August 2020. Accessed 10 September 2020. http://www.colegiomedico.cl/presidenta-de-colmed-hace-llamado-al-gobierno-a-entregar-las- 
maximas-condiciones-de-seguridad-para-plebiscito-en-pandemia/.

Correa, Martín, and Eduardo Mella. Las razones del illkun/enojo: Memoria, despojo y criminalización en el territorio mapuche de Malleco. Santiago: LOM, 2010.

Craib, Raymond B. Cry of the Renegade: Politics and poetry in interwar Chile. New York: Oxford University Press, 2016.

¿¿Cuándo es la próxima elección en Chile y qué se vota?’. T13, 26 October 2020. Accessed 29 October 2020. https://www.t13.cl/noticia/plebiscito-2020/politica/cuando-es-proxima-eleccion-chile-votoconvencion-constitucional-alcaldes-gobernadores-26-10-20.

Denning, Michael. Culture in the Age of Three Worlds. London: Verso, 2004.

Denning, Michael. 'Neither capitalist nor American: The democracy as social movement'. In Culture in the Age of Three Worlds, edited by Michael Denning, 209-26. London: Verso, 2004.

Domedel, Andrea, and Macarena Peña Y Lillo. El mayo de los pingüinos. Santiago: Ediciones Radio Universidad de Chile, 2008.

'Don Francisco lloró por la situación país: "No sabía que había tanta rabia"'. The Clinic, 21 October 2019. Accessed 10 September 2020. https://www.theclinic.cl/2019/10/21/video-don-francisco-lloro-por-lasituacion-pais-no-sabia-que-habia-tanta-rabia/?fbclid=IwAR1GKTJRA9v2YpCQIvLeBGtNp2_ 4g19maEBsYrKv0gXNVt-6H7J9HNFaEb0.

Dorfman, Ariel. 'Adiós al oasis chileno'. Página 12, 26 December 2019. Accessed 10 September 2020. https://www.pagina12.com.ar/238357-adios-al-oasis-chileno?fbclid=IwAR1kM_ 8n65NR1I1JzsGiqCSsfxAjIe0Q-XzzU2ZECtHOiLykv2AmJFgdu9Q.

'Duro rechazo a declaraciones de Piñera donde acusa que imágenes de violaciones a DD.HH. son grabadas en el extranjero'. El Desconcierto, 26 December 2019. Accessed 10 September 2020. https://www.eldesconcierto.cl/2019/12/26/video-duro-rechazo-a-declaraciones-de-pinera-dondeacusa-que-imagenes-de-violaciones-a-dd-hh-son-grabadas-en-el-extranjero/?fbclid=IwAR1kM_ 8n65NR1I1JzsGiqCSsfxAjIe0Q-XzzU2ZECtHOiLykv2AmJFgdu9Q.

'Emocionante!! "El derecho a vivir en paz" de Víctor Jara se escucha en todo el país, justo a la hora del toque de queda. Y el Teatro Municipal enaltece la canción'. Cambio21, 23 October 2019. Accessed 29 October 2020. https://cambio21.cl/videos-y-galerias/emocionante-el-derecho-a-vivir-en-paz-devctor-jara-se-escucha-en-todo-el-pas-justo-a-la-hora-del-toque-de-queda-y-el-teatro-municipalenaltece-la-cancin-ver-video-5db06d53cd49b00c54754e63.

“"En Chile algunos han perdido el humor": Ministro Larraín se defiende tras comentario sobre precio de las flores'. CNN Chile, 8 October 2019. Accessed 10 September 2020. https://www.cnnchile.com/ lodijeronencnn/entrevista-ministro-larrain-precio-flores-humor_20191008/.

'Famous Greek riot dog Loukanikos dies'. BBC, 10 October 2014. Accessed 29 October 2020. https://www.bbc.com/news/world-europe-29565725.

Fernández, Karinna, Juan Pablo Bohoslavsky, and Sebastián Smart, eds. Complicidad económica con la dictadura chilena: Un país desigual a la fuerza. Santiago: LOM, 2019.

Ferrer, Consuelo. 'Estudio ubica a Santiago en el top 10 del ranking del transporte público más caro en función del ingreso medio'. El Mercurio, 18 October 2019. Accessed 10 September 2020. https: //www.emol.com/noticias/Nacional/2019/10/18/964843/Chile-9no-mas-caro-transporte.html.

Figueroa, Francisco. Llegamos para quedarnos: Crónicas de la revuelta estudiantil. Santiago: LOM, 2013.

Flores, Jonathan. 'Piñera apunta a odio y violencia en el Congreso y desata críticas desde la oposición'. Biobiochile.cl, 14 December 2019. Accessed 21 December 2020. https://www.biobiochile.cl/noticias/nacional/chile/2019/12/14/pinera-apunta-a-odio-y-violenciaen-el-congreso-y-desata-criticas-desde-la-oposicion.shtml.

Gálvez Comandini, Ana. 'Historia del movimiento feminista en Chile en el siglo XX y su quiebre en la postdictadura'. In Transiciones: Perspectivas historiográficas sobre la postdictadura chilena 1988-2018, edited by José Ignacio Ponce, Aníbal Pérez and Nicolás Acevedo, 285-310. Valparaíso: Editorial América en Movimiento, 2018.

Garcés, Mario. Crisis social y motines populares en el 1900, 2nd edn. Santiago: LOM, 2013. 
Garcés, Mario. El despertar de la sociedad: Los movimientos sociales de América Latina y Chile. Santiago: LOM, 2012.

Garcés, Mario. Estallido social y una Nueva Constitución para Chile. Santiago: LOM, 2020. Kindle.

Garcés, Mario. 'Los movimientos sociales en la transición: A 30 años del plebiscito de 1988'. In Las largas sombras de la dictadura: A 30 años del plebiscito, edited by Julio Pinto, 91-116. Santiago: LOM, 2019.

Garcés, Mario. Pan, trabajo, justicia y libertad: Las luchas de los pobladores en dictadura (1973-1990). Santiago: LOM, 2019.

Garcés, Mario. 'Terremoto natural y terremoto social en Chile'. In El Terremoto social del Bicentenario, edited by Silvia Aguilera, 67-86. Santiago: LOM, 2010.

Garcés, Mario, and Sebastián Leiva. El golpe en La Legua: Los caminos de la historia y la memoria, 2nd edn. Santiago: LOM, 2014.

Garcés Sotomayor, Antonia, and Yanny Santa Cruz. "El parto de un nuevo ciclo político": Las movilizaciones estudiantiles entre el 2011 y el 2013'. In Transiciones: Perspectivas historiográficas sobre la postdictadura chilena 1988-2018, edited by José Ignacio Ponce, Aníbal Pérez and Nicolás Acevedo, 351-78. Valparaíso: Editorial América en Movimiento, 2018.

'Gobierno contrató campaña publicitaria “por la paz” por \$202 millones'. El Desconcierto, 25 December 2019. Accessed 10 September 2020. https://www.eldesconcierto.cl/2019/12/25/gobierno-contratocampana-publicitaria-por-la-paz-por-202-millones/.

Gobierno de Chile. 'Presidente Piñera anuncia conjunto de propuestas para una nueva agenda social'. Gob.cl, 22 October 2019. Accessed 10 September 2020. https://www.gob.cl/noticias/presidentepinera-anuncia-conjunto-de-propuestas-para-una-agenda-social/.

'Gobierno insiste en tesis de la "influencia extranjera" pese a cuestionado informe de Big Data'. Diario U Chile, 22 December 2019. Accessed 10 September 2020. https://tinyurl.com/y2g5gtez.

Godoy Sepúlveda, Eduardo. 'Una transición antes de la transición. Las transformaciones del anarquismo en Chile (1973-1994)'. In Transiciones: Perspectivas historiográficas sobre la postdictadura chilena, 1988-2018, compiled by José Ignacio Ponce, Aníbal Pérez and Nicolás Acevedo, 227-66. Valparaíso: Editorial América en Movimiento, 2018.

Grandin, Greg, and Gilbert M. Joseph, eds. A Century of Revolution: Insurgent and counterinsurgent violence during Latin America's long cold war. Durham, NC: Duke University Press, 2010.

Hite, Katherine. When the Romance Ended: Leaders of the Chilean Left, 1968-1998. New York: Columbia University Press, 1999.

Illanes Oliva, María Angélica. Chile Des-centrado: Formación socio-cultural republicana y transición capitalista (1810-1910). Santiago: LOM, 2003.

Illanes Oliva, María Angélica. "Water rights for sale": Contrarreforma en las aguas dulces y resistencia de los pueblos. Chile, 1967-2017. In Las largas sombras de la dictadura: A 30 años del plebiscito, edited by Julio Pinto, 35-58. Santiago: LOM, 2019.

'INE: La mitad de los trabajadores en Chile recibe un sueldo igual o inferior a $\$ 400.000$ al mes'. CNN Chile, 13 August 2019. Accessed 10 September 2020. https://www.cnnchile.com/economia/ ine-la-mitad-de-los-trabajadores-en-chile-recibe-un-sueldo-igual-o-inferior-a-400-000-al-mes_ 20190813/.

Instituto Nacional de Derechos Humanos (INDH). 'Informe Anual: Sobre la situación de los derechos humanos en Chile en el contexto de la crisis social, 17 Octubre-30 Noviembre 2019'. Accessed 10 September 2020. https://bibliotecadigital.indh.cl/bitstream/handle/123456789/1701/Informe\% 20Final-2019.pdf?sequence=1\&isAllowed=y.

Jara Román, Sergio. Piñera y los leones de Sanhattan: Crónica del auge de la élite financiera chilena, 2nd edn. Santiago: Planeta, 2018.

La Mura, Florencia. 'Karin Friedli, soprano y parte del Requiem por Chile: "Hay una necesidad de que la música clásica se acerque a todas las comunas"'. Palabra Pública, 14 January 2020. Accessed 10 September 2020. https://palabrapublica.uchile.cl/2020/01/14/karin-friedli-soprano-y-parte-del-requiem-porchile-hay-una-necesidad-de-que-la-musica-clasica-se-acerque-a-todas-las-comunas/. 
"La peor crisis de DD.HH. desde la dictadura": Amnistía Internacional publica informe de escenario en Chile en 2019'. CNN Chile, 27 February 2020. Accessed 10 September 2020. https://www.cnnchile.com/pais/amnistia-internacional-informe-dd-hh-chile-2019_20200227/ ?fbclid=IwAR1Ft0-XJw73siy_oXfiuLzjbDbwE2NoMnVN9zkm2ai_OflcyDdswAznh5s.

'La Tercera confirma que audio filtrado de Cecilia Morel es real'. ChileVisión Noticias, 21 October 2019. Accessed 10 September 2020. https://www.chvnoticias.cl/nacional/audio-cecilia-morel_20191021/ ?fbclid=IwAR1skds3xoZK921AxGOdwr9wpGQN-hhkYAjM3YhWHLTW41BNrjhPI-E_H1c.

Labrín, Estefanía. “Jesús habría estado aquî”: La lucha de los cristianos que llegaron a Plaza Italia'. The Clinic, 26 October 2019. Accessed 29 October 2020. https://www.theclinic.cl/2019/10/26/jesushabria-estado-aqui-la-lucha-de-los-cristianos-que-llegaron-a-plaza-italia/.

Larrondo, Pía. 'Chile el país más feliz de Sudamérica: Experto internacional que hizo el estudio de la ONU revela las claves'. El Mercurio, 24 March 2019. Accessed 10 September 2020. https://www.emol.com/noticias/Tendencias/2019/03/24/942246/Investigador-a-cargo-del-Informede-Felicidad-Mundial-Los-chilenos-estan-en-lo-correcto-cuando-piensan-que-hay-mucho-quedeberia-hacerse-para-mejorar-sus-vidas.html.

Lavín, Joaquín. Chile: Revolución silenciosa. Santiago: Zig Zag, 1987.

Lepe, Nathaly. 'El derecho de vivir en paz: las sobrecogedoras versiones de la canción de Víctor Jara que ha renacido como un himno contra la represión'. Metro World News, 23 October 2019. Accessed 29 October 2020. https://www.metroworldnews.com/chile/social/2019/10/23/derecho-vivir-paz-victorjara-cancion-protestas-toque-queda?from $=\mathrm{cl}$.

Ley $\mathrm{N}^{\circ} 20.840,2015$. 'Sustituye el sistema electoral binominal por uno de carácter proporcional inclusivo y fortalece la representatividad del Congreso Nacional'. Biblioteca del Congreso Nacional de Chile. Accessed 10 September 2020. https://www.bcn.cl/historiapolitica/elecciones/detalle_eleccion? handle $=10221.1 / 63227 \&$ periodo $=1990-2022$.

Lira, Elizabeth, and Brian Loveman. El espejismo de la reconciliación politica, Chile 1990-2002. Santiago: LOM, 2002.

Lira, Elizabeth, and Brian Loveman. Políticas de reparación, Chile 1990-2004. Santiago: LOM, 2005.

'Los héroes de las protestas en Chile'. El Universal (Mexico), 7 November 2019. Accessed 10 September 2020. https://www.eluniversal.com.mx/mundo/de-pareman-al-perro-matapacos-los-heroes-de-lasprotestas-en-chile.

'Los homenajes gráficos al "Negro Matapacos," el perro de las marchas que se convirtió en ícono de estas manifestaciones'. The Clinic, 5 November 2019. Accessed 10 September 2020. https://www.theclinic.cl/2019/11/05/los-homenajes-al-negro-matapacos-el-perrode-las-marchas-que-se-convirtio-el-icono-de-estas-manifestaciones/.

'Mariano Puga por crisis en Chile: "Piñera no entiende lo que está detrás del clamor de la gente". CNN Chile, 24 October 2019. Accessed 29 October 2020. https://www.cnnchile.com/pais/mariano-pugapinera-no-entiende-clamor_20191024/.

'Masiva manifestación pacífica se realiza en Plaza Ñuñoa'. 24 Horas TVN Chile, 20 October 2019. Accessed 10 September 2020. https://www.youtube.com/watch?v=Lu7HkgvyF88.

Memmott, Mark. "'Riot Dog” Is Back in Athens'. National Public Radio (USA), 28 June 2011. Accessed 29 October 2020. https://www.npr.org/sections/thetwo-way/2011/06/28/137474626/riot-dog-is-backin-athens.

Metro de Santiago. 'Balance daños 19 de octubre 2019'. 20 October 2019. Accessed 10 September 2020. https://www.metro.cl/noticias/balance-danos-19-de-octubre-2019.

Milos, Pedro. 2 de abril de 1957: Historia y memoria. Santiago: LOM, 2007.

Molina, Paula. 'Plebiscito en Chile: los temas clave que tendrá que debatir la histórica Convención que redactará la nueva Constitución'. BBC News Mundo, 28 October 2020. Accessed 29 October 2020. https://www.bbc.com/mundo/noticias-america-latina-54717647.

Moulian, Tomás. Chile actual: Anatomía de un mito. Santiago: LOM, 1997.

Musicxs de Chile. 'El Derecho de Vivir en Paz (Video Oficial 2019)'. YouTube, 27 October 2019. Accessed 10 September 2020. https://www.youtube.com/watch?v=wlfAf2AibA8. 
Muzzopappa, María Eva, and Alicia Salomone. 'Sobre la legitimidad de la violencia. Reflexiones a partir de la Primera Línea en el debate público'. El Desconcierto, 9 January 2020. Accessed 10 September 2020. https://www.eldesconcierto.cl/2020/01/09/sobre-la-legitimidad-de-la-violencia-reflexionesa-partir-de-la-primera-linea-en-el-debate-publico/.

Naciones Unidas, Oficina del Alto Comisionado de Derechos Humanos. 'Informe sobre la Misión a Chile, 30 de octubre-22 de noviembre de 2019'. Accessed 10 September 2020. https://www.ohchr.org/ Documents/Countries/CL/Report_Chile_2019_SP.pdf.

“"Negro Matapacos", "Pareman” y "Baila Pikachu”: Los íconos del estallido social en Chile'. CNN Chile, 17 November 2019. Accessed 10 September 2020. https://www.youtube.com/watch?v=21rdwaTW-Rk.

Organización de los Estados Americanos (OEA). Comunicado de Prensa, 'CIDH condena el uso excesivo de la fuerza en el contexto de las protestas sociales en Chile, expresa su grave preocupación por el elevado número de denuncias y rechaza toda forma de violencia'. 6 December 2019. Accessed 10 September 2020. http://www.oas.org/es/cidh/prensa/comunicados/2019/317.asp.

'Orquesta toca “El pueblo unido, jamás será vencido!”'. La Jornada (Mexico), 29 October 2019. Accessed 10 September 2020. https://videos.jornada.com.mx/video/41010398/orquesta-toca-el-pueblo-unidojamas-sera-vencido/.

Pairican Padilla, Fernando. 'La gran revuelta Mapuche 1990-2010'. In Transiciones: Perspectivas historiográficas sobre la postdictadura chilena, 1988-2018, edited by José Ignacio Ponce, Aníbal Pérez and Nicolás Acevedo, 267-84. Valparaíso: Editorial América en Movimiento, 2018.

Paley, Julia. Marketing Democracy: Power and Social Movements in Post-Dictatorship Chile. Berkeley: University of California Press, 2001.

'Piñera dice que muchos de los videos sobre violaciones a los DDHH divulgados durante crisis "son filmados fuera de Chile". La Tercera, 25 December 2019. Accessed 10 September 2020. https://www.latercera.com/politica/noticia/pinera-dice-muchos-losvideos-aparecen-violaciones-los-ddhh-crisis-filmados-chile/951808/?fbclid=IwAR2NiSaknchVrmRnAL622bcBYKjjLA1J6IN5XbjmvhiuGXD845xaO4eYyY.

'Piñera: "Estamos en guerra contra un enemigo poderoso". CNN Chile, 21 October 2019. Accessed 10 September 2020. https://www.cnnchile.com/pais/pinera-estamos-en-guerra-contra-un-enemigopoderoso_20191021/.

'Piñera: "He recibido información que afirma que aquí hubo intervención de Gobiernos extranjeros"'. CNN Chile, 9 November 2019. Accessed 10 September 2020. https://www.cnnchile.com/pais/pineraaqui-hubo-intervencion-de-gobiernos-extranjeros_20191109/.

Pinto, Julio, ed. Cuando hicimos historia: La experiencia de la Unidad Popular. Santiago: LOM, 2005.

Pinto, Julio, ed. Fiesta y drama: Nuevas historias de la Unidad Popular. Santiago: LOM, 2014.

Pinto, Julio, ed. Las largas sombras de la dictadura: A 30 años del plebiscito. Santiago: LOM, 2019.

Ponce, José Ignacio, Aníbal Pérez, and Nicolás Acevedo, comps. Transiciones: Perspectivas historiográficas sobre la postdictadura chilena, 1988-2018. Valparaíso: Editorial América en Movimiento, 2018.

'Presidente Piñera: Chile es un verdadero oasis en una América Latina convulsionada'. Cooperativa.cl, 9 October 2019. Accessed 10 September 2020. https://www.cooperativa.cl/noticias/pais/presidente-pinera/ presidente-pinera-chile-es-un-verdadero-oasis-en-una-america-latina/2019-10-09/063956.html.

'Presidente Piñera: "Sabemos perfectamente bien qué están preparando para mañana"'. Meganoticias, 20 October 2019. Accessed 10 September 2020. https://www.meganoticias.cl/nacional/279769sebastian-pinera-guerra-estado-de-emergencia-toque-de-queda-incidentes-manifestaciones.html.

'Protestas en Chile: "El baile de los que sobran", la mítica canción de Los Prisioneros que se convirtió en el himno de la marcha más grande del país'. BBC News Mundo, 26 October 2019. Accessed 10 September 2020. https://www.bbc.com/mundo/noticias-50191283.

Ramírez, Fresia. 'Norte, centro y sur: cacerolazos a lo largo de Chile culminan primera noche de marzo'. Publimetro.cl, 1 March 2020. Accessed 10 September 2020. https://www.metroworldnews.com/chile/noticias/2020/03/01/norte-centro-sur-cacerolazoslo-largo-chile-culminan-primera-noche-marzo?from=cl. 
Víctor Ramírez, dir. Documental Matapaco. Santiago: Enmarcha Films, 2013. Accessed 10 September 2020. https://www.youtube.com/watch?v=wiEFhAAWCiw\&feature=share $\&$ fbclid= IwAR2z0WbNK8MM135FdZnKeNPW1qWf5YjeiqEIBwJEECEDL3zRL4N3ELH1qAY\&has_ verified $=1$.

Red de Historiadoras Feministas, ‘ $¡ N o$ son 30 pesos, son 30 años!: Las protestas desde la historia feminista'. El Desconcierto, 22 October 2019. Accessed 10 September 2020. https://www.eldesconcierto.cl/2019/10/22/no-son-30-pesos-son-30-anos-las-protestas-desdela-historia-feminista/.

'REDESI \#CacerolazoPorMi10: Protestas tras anuncios de Piñera continúan a horas de que se vote el retiro de fondos previsionales'. El Desconcierto, 24 July 2020. Accessed 10 September 2020. https://www.eldesconcierto.cl/2020/07/14/redes-cacerolazopormi10-protestas-tras-anunciosde-pinera-continuan-a-horas-de-que-se-vote-el-retiro-de-fondos-previsionales/.

Reyes, Verónica. 'La deuda en los hogares chilenos sigue subiendo y equivale al $75 \%$ del ingreso disponible'. Biobiochile.cl, 7 January 2020. Accessed 10 September 2020. https://www.biobiochile.cl/noticias/economia/actualidad-economica/2020/01/07/la-deudaen-los-hogares-chilenos-sigue-subiendo-y-equivale-al-75-del-ingreso-disponible.shtml.

rojas, juan. “"El pueblo unido jamás será vencido" - Víctor Jara Sinfónico'. 10 November 2019. Accessed 10 September 2020. https://www.youtube.com/watch?v=XgnXAymPyGE.

Rojo, Grinor. 'Saqueos'. In El Terremoto social del Bicentenario, edited by Silvia Aguilera, 103-14. Santiago: LOM, 2010.

Salazar, Gabriel. En el nombre del poder popular constituyente (Chile, Siglo XXI). Santiago: LOM, 2011. Salazar, Gabriel. La historia desde abajo y desde dentro. Santiago: Facultad de Artes, Universidad de Chile, 2003.

Salazar, Gabriel. La violencia politica popular en las "Grandes Alamedas": La violencia en Chile 1947-1987 (Una perspectiva histórico popular), 2nd edn. Santiago: LOM, 2006.

Schlotterbeck, Marian E. Beyond the Vanguard: Everyday Revolutionaries in Allende's Chile. Berkeley: University of California Press, 2018.

Schneider, Cathy Lisa. Shantytown Protest in Pinochet's Chile. Philadelphia, PA: Temple University Press, 1995.

“Sebastián Piñera advierte que manifestantes tienen la logística de "una organización criminal”'. Diario $U$ Chile, 20 October 2019. Accessed 10 September 2020. https://radio.uchile.cl/2019/10/20/sebastianpinera-advierte-que-manifestantes-tienen-la-logistica-de-una-organizacion-criminal/?fbclid= IwAR08gSy_rT4LqVntbRzrU7o8ah5174aSijgYQQyruwOpILDNhommNF0F1M0.

'Sebastián Piñera y equivocaciones durante estallido social: "He cometido errores. Lo lamento y pido perdón por ellos"”. CNN Chile, 29 December 2019. Accessed 10 September 2020. https://www. cnnchile.com/pais/sebastian-pinera-estallido-social-errores-pido-perdon_20191229/.

Sepúlveda, Paulina. ¿¿Qué tan desigual es Chile?' Qué Pasa (de La Tercera), 21 October 2019, reproduced by the Centro de Estudios de Conflicto y Cohesión Social (COES). Accessed 10 September 2020. https://coes.cl/prensa-que-tan-desigual-es-chile/?fbclid= IwAR08KPFrVRSD6ytiWVjabWjwNFk1t9-SQyRg5PJhDhsvSQ9cPK8-wHEqOxQ.

“"Si una persona gasta $\$ 50.000$ en locomoción no puede comer": La aplaudida intervención de una transeúnte que apoya la evasion'. El Desconcierto, 18 October 2019. Accessed 10 September 2020. https://www.eldesconcierto.cl/2019/10/18/video-si-una-persona-gasta-50-000-en-locomocion-nopuede-comer-la-aplaudida-intervencion-de-una-transeunte-que-apoya-la-evasion/.

Stern, Steve J. The Memory Box of Pinochet's Chile Trilogy. Durham, NC: Duke University Press, 2006-10.

Stern, Steve J., and Peter Winn. 'El tortuoso camino chileno a la memorialización'. In No hay mañana sin ayer: Batallas por la memoria histórica en el Cono Sur, edited by Peter Winn, Steve J. Stern, Federico Lorenz and Aldo Marchesi, 205-326. Santiago: LOM, 2014.

Stamouli, Nektaria. 'Loukanikos, the Greek protest dog, dies'. Wall Street Journal, 9 October 2014. Accessed 29 October 2020. https://www.wsj.com/articles/BL-DISPATCHB-4146. 
Tinsman, Heidi. Buying into the Regime: Grapes and consumption in cold war Chile and the United States. Durham, NC: Duke University Press, 2014.

Tinsman, Heidi. 'La democracia chilena: Las protestas y las herencias de la dictadura'. NACLA, 19 November 2019. Accessed 10 September 2020. https://nacla.org/news/2019/11/19/la-democraciachilena-las-protestas-y-las-herencias-de-la-dictadura.

Trumper, Camilo. Ephemeral Histories: Public Art, Politics, and the Struggle for the Streets in Chile. Berkeley: University of California Press, 2016.

Valdivia Ortiz de Zárate, Verónica. 'Recobrando la democracia: La militarización del conflicto político en Chile'. In Las largas sombras de la dictadura: A 30 años del plebiscito, edited by Julio Pinto, 139-67. Santiago: LOM, 2019.

Valdivia Ortiz de Zárate, Verónica, Rolando Álvarez Vallejos, and Karen Donoso Fritz. La alcaldización de la política: Los municipios en la dictadura pinochetista. Santiago: LOM, 2012.

Valenzuela Sebik, María José. 'Primera evasión masiva de marzo: manifestantes saltaron torniquetes en estación Pudahuel'. Publimetro.cl, 2 March 2020. Accessed 10 September 2020. https://www.publimetro.cl/cl/noticias/2020/03/02/primera-evasion-masivamarzo-manifestantes-saltaron-torniquetes-estacion-pudahuel.html?fbclid=IwAR2MOk33GCpt3iaSbLz5nQtNcvWMafWH4XdITZqRRhbm6ahu8PiPPFoVqk.

Víctor Jara - Música, 'El derecho de vivir en paz - Biblioteca Nacional - Octubre 2019'. YouTube, 25 December 2019. https://www.youtube.com/watch?v=B0N0tYE6jg8.

Winn, Peter. 'The Furies of the Andes: Violence and terror in the Chilean revolution and counterrevolution'. In A Century of Revolution: Insurgent and counterinsurgent violence during Latin America's long cold war, edited by Greg Grandin and Gilbert M. Joseph, 239-75. Durham, NC: Duke University Press, 2010.

Winn, Peter, ed. Victims of the Chilean Miracle: Workers and neoliberalism in the Pinochet era, 1973-2002. Durham, NC: Duke University Press, 2004.

Winn, Peter. Weavers of Revolution: The Yarur workers and Chile's road to socialism. New York: Oxford University Press, 1989.

Winn, Peter, Steve J. Stern, Federico Lorenz, and Aldo Marchesi. No hay mañana sin ayer: Batallas por la memoria histórica en el Cono Sur. Santiago: LOM, 2014.

Wright, Thomas C. Impunity, Human Rights, and Democracy: Chile and Argentina, 1990-2005. Austin: University of Texas Press, 2014.

Zerán, Faride, ed. El mayo feminista: La rebelión contra el patriarcado. Santiago: LOM, 2018.

Zibechi, Raúl. Territories in Resistance: A cartography of Latin American social movements, translated by Ramor Ryan. Oakland, CA: AK Press, 2012. 